\title{
KEBUTUHAN PERAWATAN ORTODONSI BERDASARKAN INDEX OF ORTHODONTIC TREATMENT NEED DI SMP KATOLIK THEODORUS KOTAMOBAGU
}

\author{
${ }^{1}$ Christy Hansu \\ ${ }^{2}$ P.S. Anindita \\ ${ }^{3}$ Ni Wayan Mariati
}

\author{
${ }^{1}$ Kandidat Skripsi Program Studi Kedokteran Gigi Universitas Sam Ratulangi Manado \\ ${ }^{2}$ Program Studi Kedokteran Gigi Fakultas Kedokteran Universitas Sam Ratulangi Manado \\ Email:ps_anindita@yahoo.com
}

\begin{abstract}
In the year of 1995 World Health Organization (WHO) counted the prevelensi needs of orthodontic treatment in 10 industrial countries, where the needs of the orthodontic treatment around $21-64 \%$. At this time they have never done the research of the needs of orthodontic treatment in the city of Kotamobagu. This research aims to measure the requirement of orthodontic treatment based on Index of Orthodontic Treatment Need (IOTN). IOTN consists of two parts: Aesthetic Component ( AC) and Dental Health Component ( DHC). This is a descriptive observational study, conducted in Theodorus Catholic junior high school Kota Kotamobagu in April 2013. The population consist of all Theodorus Catholic junior high school students between 13-14 years old that are 222 students and only 143 students are includes in the sampling frame. Samples were then checked by use IOTN (AC and DHC). The results showed that based on the AC, 95\% no need treatment or mild treatment, $4.2 \%$ need borderline treatment and $0.7 \%$ great need treatment while on DHC, $85.3 \%$ no need treatment or only light treatment, $13.3 \%$ need borderline treatment and $1.4 \%$ great need treatment. The results of AC shows less valid because the AC just measured subjectively by judging only by the looks of the patients teeth, compare to the DHC where we measure objectively by checking and measuring the condition of the teeth and mouth. With that said the result of this research shows that they who has their teeth from the AC angle looks good, but from the DHC angle they need treatment.
\end{abstract}

Keywords: Index of Orthodontic Treatment Need, Aesthetic Component, Dental Health.

Salah satu jenis perawatan gigi yang banyak diminati oleh remaja pada saat ini adalah pemakaian kawat gigi atau dalam istilah kedokteran gigi disebut perawatan ortodonsi. Para remaja melakukan perawatan ortodonsi dengan berbagai macam tujuan yaitu, memperbaiki susunan gigi, memperbaiki penampilan wajah, meningkatkan fungsi bicara dan banyak yang bertujuan untuk gaya. ${ }^{1}$ Penampilan pribadi tidak bergantung pada penilaian objektif dan kebutuhan perawatan tergantung sebagian besar pada keinginan pasien maupun orang tuanya meskipun demikian minat untuk perawatan mengubah profil wajah melalui perawatan ortodonsi masih kurang. ${ }^{2}$
Secara teori sebenarnya perawatan ortodonsi memiliki tujuan yang luas dan tidak hanya sekedar melakukan koreksi maloklusi. Salzman menyatakan bahwa tujuan perawatan ortodonsi antara lain adalah untuk memperbaiki estetik yaitu mengoreksi letak dan susunan gigi serta mencegah terjadinya keadaan yang abnormal dari bentuk muka. ${ }^{2}$ Perawatan ortodonsi antara lain direkomendasikan untuk tujuan fungsional yaitu meningkatkan kemampuan fungsi dan bicara. ${ }^{1}$ Dengan perawatan ortodonsi letak gigi dan rahang yang tidak normal diperbaiki sehingga didapatkan fungsi geligi, estetik geligi dan wajah yang baik sehingga meningkatkan 
100 Jurnal e-GiGi (eG), Volume 1, Nomor 2, September 2013, hlm. 99-104

kesehatan psikososial seseorang. ${ }^{3}$

Menurut World Health Organization maloklusi yang berupa cacat atau mengganggu fungsi kemungkinan dapat menyebabkan rintangan bagi kesehatan fisik maupun emosional dari pasien sehingga membutuhkan suatu perawatan. ${ }^{4}$ Tinjauan psikologis menyebutkan bahwa maloklusi yang mempengaruhi estetik wajah dan penampilan seseorang dapat memberikan dampak yang tidak menguntungkan pada perkembangan psikologis remaja. Definisi yang umum seperti ini terutama digunakan dalam menilai kebutuhan perawatan bagi pasien. ${ }^{2}$

Remaja masa kini sering dijumpai mengalami maloklusi tetapi tidak melakukan perawatan. Mungkin mereka tidak merasa mangalami maloklusi atau tidak tahu bahwa dirinya membutuhkan perawatan ortodonsi. Beberapa remaja lain menjadi rendah diri karena penampilan yang kurang menarik, atau kurang sempurnanya fungsi bicara sebagai akibat maloklusi. Adanya perbedaan presepsi dalam menilai maloklusi kaitannya dengan perawatan ortodonsi dan bervariasinya tujuan melakukan perawatan ortodonsi memunculkan beberapa macam indeks untuk mengukur kebutuhan perawatan ortodonsi diantaranya Index of Orthodontic Treatment Need (IOTN). ${ }^{3}$

Index of Orthodontic Treatment Need disusun oleh Brook dan Shaw dimodifikasi oleh Richmond pada tahun 1989. Indeks ini telah mendapatkan pengakuan nasional dan internasional sebagai metode yang sederhana, reliable dan valid, secara objektif menilai kebutuhan akan perawatan. Index of Orthodontic Treatment Need terdiri dari 2 komponen, yaitu Aesthetic Component (AC) dan Dental Health Component (DHC). ${ }^{5}$ Aesthetic Component menilai persepsi seseorang tentang penampilan gigi-geligi pasien melalui sebuah skala fotograf, dimana terdapat 10-poin yang menunjukan tingkatan penampilan gigi-geligi yang secara estetik terlihat paling menarik dan 10 foto mewakili gigi-geligi yang secara estetik paling tidak menarik. Dental Health Component menilai beberapa jenis maloklusi seperti overjet, overbite, openbite, crossbite, crowding, erupsi palatal yang terhalang, anomali palatal dan bibir, serta hypodonsia. ${ }^{1}$

World Health Organization (WHO) pada tahun 1995 telah mengukur prevalensi kebutuhan perawatan ortodonsi di 10 negara industri, dimana kebutuhan perawatan ortodonsi berkisar 21-64\%. ${ }^{6}$ Penelitian sejenistelah dilakukan di Manado pada tahun 2010 tentang kebutuhan perawatan ortodonsi pada SMP Eben Heazer I usia 1314 tahun oleh Musyulianti, dimana kebutuhan perawatan ortodonsi berkisar 328\%. ${ }^{7}$ Penelitian tentang kebutuhan perawatan ortodonsi berdasarkan IOTN juga ditemukan pada siswa SMA di Kecamatan Malalayang Manado dilakukan pada tahun 2011 oleh Endang S, dengan 5-17\% membutuhkan perawatan ortodonsi. ${ }^{8}$ Hasil agak berbeda pada 3 SMP di Jakarta Selatan kelas 1 usia 12-13 tahun yang menunjukkan sebagian besar subjek penelitian membutuhkan perawatan $63,3 \%$, pada penelitian Emmadita tahun 2011 di SDK 6 BPK penabur Bandung kelompok usia 11-12 tahun ditemukan hasil yang sama dengan 59\% membutuhkan perawatan ortodonsi. ${ }^{5,9}$

\section{BAHAN DAN METODE}

Penelitian dilakukan di SMP katolik Theodorus Kotamobagu pada bulan April 2013. Sampel pada penelitian ini adalah siswa-siswi yang berusia 13-14 tahun yang berjumlah 143 siswa. Metode pengambilan sampel yang digunakan dalam penelitian ini adalah purposive sampling.

Data primer berupa data usia siswa, data jenis kelamin dan hasil pengukuran AC dan DHC berdasarkan IOTN yang dilakukan sendiri oleh peneliti. Data sekunder meliputi data jumlah siswa dan data sosial ekonomi orang tua siswa yang diperoleh dari sekolah.

Data disajikan dalam bentuk tabel berdasarkan jenis kelamin, usia, AC dan DHC, kemudian dianalisis berdasarkan hasil persentase.

\section{HASIL PENELITIAN}

Karakteristik subjek penelitian berdasarkan jenis kelamin dapat dilihat pada Tabel 1. 
Hansu, Anindita, Mariati; Kebutuhan Perawatan Ortodonsi... 101

Tabel 1. Distribusi subjek penelitian berdasarkan jenis kelamin

\begin{tabular}{ccrr}
\hline & & Jumlah & \% \\
\hline \multirow{2}{*}{ Jenis } & Laki-laki & 60 & 42 \\
Kelamin & Perempuan & 83 & 58 \\
& Jumlah & 143 & 100 \\
\hline
\end{tabular}

Tabel 2. Distribusi berdasarkan usia

\begin{tabular}{llrc}
\hline & & Jumlah & \% \\
\hline \multirow{2}{*}{ Usia } & 13 tahun & 31 & 21,7 \\
& 14 tahun & 112 & 78,3 \\
& Jumlah & 143 & 100 \\
\hline
\end{tabular}

Hasil penelitian berdasarkan AC dapat dikelompokan menurut kriteria tidak/sedikit butuh perawatan, butuh perawatan borderline, dan sangat butuh perawatan (Tabel 3).

Hasil penelitian berdasarkan DHC juga dapat dikelompokkan menurut kriteria tidak/ sedikit butuh perawatan, perawatan borderline, dan sangat butuh perawatan (Tabel 4).

Hasil pemeriksaan AC dapat di distribusikan berdasarkan jenis kelamin laki-laki dan perempuan (Tabel 5).

Hasil pemeriksaan DHC juga dapat dikelompokkan berdasarkan jenis kelamin (Tabel 6).

Hasil penelitian dapat dibandingkan berdasarkan AC dan DHC (Tabel 7).

Tabel 3. Distribusi AC pada subjek penelitian

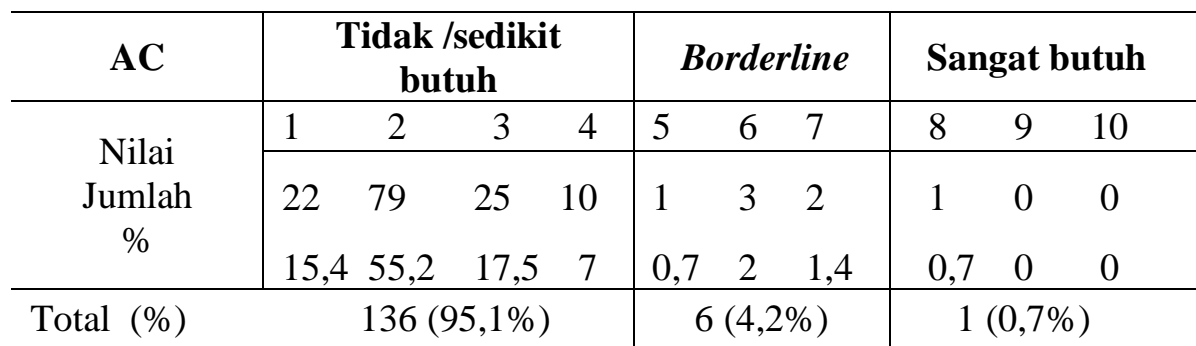

Tabel 4. Distribusi DHC pada subjek penelitian

\begin{tabular}{c|cc|c|cc}
\hline $\begin{array}{c}\text { Dental Health Component } \\
\text { (DHC) }\end{array}$ & \multicolumn{2}{|c|}{$\begin{array}{c}\text { Tidak/sedikit } \\
\text { butuh }\end{array}$} & Borderline & \multicolumn{2}{|c}{ Sangat butuh } \\
\hline Nilai & 1 & 2 & 3 & 4 & 5 \\
\cline { 2 - 7 } Jumlah & 11 & 111 & 19 & 2 & 0 \\
$\%$ & 7,7 & 77,6 & 13,3 & 1,4 & 0 \\
\hline Total & \multicolumn{2}{|c|}{$122(85,3 \%)$} & $19(13,3 \%)$ & \multicolumn{2}{|c}{$2(1,4 \%)$} \\
\hline
\end{tabular}

Tabel 5. Distribusi AC berdasarkan jenis kelamin

\begin{tabular}{c|c|l|c|l|l|l|l|l|l|r}
\hline AC & \multicolumn{3}{|c|}{ Tidak/Sedikit butuh } & \multicolumn{3}{c|}{ Borderline } & \multicolumn{3}{c}{ Sangat butuh } \\
\hline Nilai & 1 & 2 & 3 & 4 & 5 & 6 & 7 & 8 & 9 & 10 \\
\cline { 2 - 11 } & 11 & 30 & 10 & 4 & 0 & 2 & 2 & 1 & 0 & 0 \\
$\%$ & 7,7 & 21 & 7 & 2,8 & 0 & 1,4 & 1,4 & 0,7 & 0 & 0 \\
\hline Total (\%) & \multicolumn{3}{|c|}{$55(38,5 \%)$} & \multicolumn{3}{c|}{$4(2,8 \%)$} & \multicolumn{3}{|c|}{$1(0,7 \%)$} \\
\hline Perempuan & 11 & 49 & 15 & 6 & 1 & 1 & 0 & 0 & 0 & 0 \\
$\%$ & 7,7 & 34,3 & 10,5 & 4,2 & 0,7 & 0,7 & 0 & 0 & 0 & 0 \\
\hline Total (\%) & \multicolumn{3}{c|c}{$81(56,6 \%)$} & \multicolumn{3}{c|}{$2(1,4 \%)$} & \multicolumn{3}{c}{0} \\
\hline
\end{tabular}


102 Jurnal e-GiGi (eG), Volume 1, Nomor 2, September 2013, hlm. 99-104

Tabel 6. Distribusi DHC berdasarkan jenis kelamin

\begin{tabular}{|c|c|c|c|c|c|}
\hline \multirow{2}{*}{$\begin{array}{c}\text { DHC } \\
\text { Nilai } \\
\end{array}$} & \multicolumn{2}{|c|}{$\begin{array}{c}\text { Tidak/sedikit } \\
\text { butuh }\end{array}$} & \multirow{2}{*}{$\begin{array}{c}\text { Borderline } \\
3 \\
\end{array}$} & \multicolumn{2}{|c|}{ Sangat butuh } \\
\hline & 1 & 2 & & 4 & 5 \\
\hline Laki-laki & 4 & 47 & 7 & 2 & 0 \\
\hline$\%$ & 2,8 & 32,9 & 4,9 & 1,4 & 0 \\
\hline Total (\%) & \multicolumn{2}{|c|}{$51(35,7 \%)$} & $7(4,9 \%)$ & \multicolumn{2}{|c|}{$2(1,4 \%)$} \\
\hline Perempuan & 7 & 64 & 12 & 0 & 0 \\
\hline$\%$ & 4,9 & 44,8 & 8,4 & 0 & 0 \\
\hline Total (\%) & \multicolumn{2}{|c|}{$71(49,7 \%)$} & $12(8,4 \%)$ & \multicolumn{2}{|c|}{0} \\
\hline
\end{tabular}

Tabel 7. Distribusi AC dan DHC

\begin{tabular}{c|cc|cc}
\hline \multirow{2}{*}{ Kebutuhan perawatan } & \multicolumn{3}{|c|}{$\begin{array}{c}\text { Aesthetic Component } \\
\text { (AC) }\end{array}$} & \multicolumn{2}{c}{$\begin{array}{c}\text { Dental Health Component } \\
\text { (DHC) }\end{array}$} \\
\cline { 2 - 5 } & Jumlah & $\%$ & Jumlah & $\%$ \\
\hline Tidak/sedikit butuh & 136 & 95,1 & 122 & 85,3 \\
\cline { 1 - 4 } Borderline & 6 & 4,2 & 19 & 13,3 \\
\cline { 1 - 1 } Sangat butuh & 1 & 0,7 & 2 & 1,4 \\
\hline Total & 143 & 100 & 143 & 100 \\
\hline
\end{tabular}

\section{BAHASAN}

Berdasarkan hasil pemeriksaan AC (Tabel 3) subjek penelitian sebagian besar tidak/sedikit membutuhkan perawatan (95,1\%). Hasil ini dapat disebabkan oleh beberapa hal seperti status ekonomi, hal ini didukung dengan penelitian Mandal di Manchester pada tahun 2000 yang menemukan bahwa status ekonomi mempengaruhi kebutuhan perawatan ortodonsi dan penelitian pada 483 anak di Turki tahun 1994 oleh Guray menunjukkan pada subjek dengan status ekonomi yang rendah $72,26 \%$ membutuhkan perawatan ortodonsi dan $27,74 \%$ tidak butuh perawatan ortodonsi. ${ }^{1}$ Status sosial ekonomi yang lebih tinggi banyak yang tidak membutukan perawatan dibanding dengan status sosial ekonomi yang lebih rendah. Sekolah Menengah Pertama Katolik Theodorus Kotamobagu memiliki tingkat sosial ekonomi lebih baik dibandingkan sekolah yang lain, sehingga tingka tingkat maloklusi bisa ditekan sejak dini.

Latar belakang pendidikan orang tua yang tinggi juga mempengaruhi kebutuhan akan perawatan ortodonsi yang lebih rendah.
Kesadaran mereka untuk melakukan kunjungan ke dokter gigi dalam hal perawatan lebih tinggi dikarenakan keadaan sosial ekonomi yang menunjang. Pengetahuan orang tua juga berpengaruh, pada penelitian Agusni di Surabaya tahun 2007 ditemukan bahwa pada ayah dengan latar belakang pendidikan yang lebih tinggi terdapat kebutuhan perawatan ortodonsi yang lebih rendah. ${ }^{5}$ Hasil penelitian ini tidak berbeda jauh pada penelitian di SMA sekecamatan Malalayang usia 16-18 tahun di Manado oleh Endang S pada tahun 2011, dimana dari pemerikasaan AC yang tidak/ sedikit membutuhkan perawatan $(81,86 \%){ }^{7}$

Kelompok AC yang membutuhkan perawatan borderline sebesar 4,2\%. Kelompok dengan kategori sangat membutuhkan perawatan sebesar $0,7 \%$. Status sosial ekonomi yang baik dan latar belakang orang tua yang tinggi memang berperan penting, namun masih ada anak yang perlu perawatan mungkin dikarenakan ada maloklusi yang terjadi karena faktor keturunan orang tua, seperti kelainan rahang dan gigi serta kekurangan nutrisi sejak lahir.

Penilaian DHC pada penelitian ini (Tabel 4) menunjukkan sebagian besar 
subjek penelitian tidak/sedikit membutuhkan perawatan sebesar 85,3\%. Kelompok yang membutuhkan perawatan borderline sebesar $13,3 \%$, dan sangat butuh perawatan ortodonsi sebesar $1,4 \%$. Hasil yang sama juga ditunjukkan pada penelitian di SMP Kr. Eben Heazer usia 13-14 tahun di Manado oleh Muslyanti pada tahun 2010, dimana $62,5 \%$ tidak membutuhkan perawatan. Tidak banyak siswa yang membutuhkan perawatan ortodonsi pada Sekolah Menengah Pertama Katolik Thoedorus bisa disebabkan siswa-siswi menyadari akan kesehatan gigi. Perhatian, didikan, pengetahuan orang tua terhadap pemeliharaan kesehatan gigi sehingga faktor-faktor yang dapat menyebabkan maloklusi bisa dihindari sejak dini, peneliti hanya bisa berasumsi karena dalam penelitian ini tidak meneliti faktor etiologi maloklusi. $^{2}$

Berdasarkan jenis kelamin, penelitian ini memperlihatkan bahwa hasil pemeriksaan AC berbeda antara laki-laki dan perempuan. Hal tersebut dapat terlihat pada kelompok yang tidak/sedikit membutuhkan perawatan (Tabel 5), perbandingan laki-laki dan perempuan yaitu 55 siswa (38,5\%) dan 81 siswa (56,6\%). Agusni pada penelitiannya di Surabaya menemukan bahwa anak perempuan lebih memiliki keinginan untuk perawatan ortodonsi. ${ }^{1}$ Kelompok yang butuh perawatan borderline pada laki-laki (2,8\%) dan perempuan $(1,4 \%)$, sedangkan kelompok yang sangat membutuhkan perawatan sebesar $0,7 \%$ hanya pada laki-laki. Hasil yang sama diperoleh pula pada pemeriksaan DHC (Tabel 6), yang menunjukkan hanya ada sedikit perbedaan antara laki-laki dan perempuan. Kelompok terbanyak adalah mereka yang tidak/sedikit membutuhkan perawatan laki-laki $(35,7 \%)$ dan perempuan (49,7\%). Ucuncu pada penelitiannya di Turki tahun 2001 menemukan tidak ada perbedaan nilai yang signifikan antara lakilaki dan perempuan. ${ }^{5}$ Pada penelitian ini terlihat kebutuhan akan perawatan ortodonsi pada anak perempuan sedikit lebih tinggi dibanding anak laki-laki, karena perempuan lebih memperhatikan estetik dibanding dengan laki-laki.
Penelitian yang dilakukan pada siswa Sekolah Menengah Pertama Katolik Theodorus Kota Kotamobagu dapat dilihat bahwa nilai AC dan DHC memiliki kesamaan dengan kelompok yang tidak/ sedikit membutuhkan perawatan merupakan kelompok terbanyak dengan AC (95,1\%) dan DHC (85,3\%), sedangkan kelompok yang membutuhkan perawatan borderline dengan AC (4,2\%) dan DHC (13,3\%) dan yang paling sedikit kelompok yang sangat membutuhkan perawatan dengan AC (0,7\%) dan DHC 2 (1,4\%). Hasil penelitian secara keseluruhan berdasarkan AC dan DHC tidak jauh berbeda dengan hasil dari Musyulianti, dimana berdasarkan AC yang tidak/sedikit membutuhan perawatan (93,75\%), butuh perawatan borderline (3,1\%) dan sangat butuh perawatan $(3,1 \%)$. Berdasarkan DHC yang tidak/sedikit membutuhkan (62,5\%), butuh perawatan borderline $(9,38 \%)$ dan sangat butuh perawatan $(28,12 \%){ }^{7}$ Penelian dengan hasil yang tidak jauh berbeda ini mungkin disebabkan karena penelitian dilakukan di Sekolah swasta dengan tingkat sosial ekonomi orang tua menengah ke atas.

Banyak pendapat mengenai hasil AC yang kurang valid karena pemeriksaan AC hanya menilai secara subjektif dengan melihat sisi penampilan dari gigi pasien, dibandingkan dengan pemerikasaan DHC yang secara objektif dengan melakukan pemeriksaan dan pengukuran keadaan gigi dan mulut. Dengan demikian hasil penelitian menunjukkan bahwa mereka yang berdasarkan hasil AC penampilan gigi-geliginya terlihat baik, namun berdasarkan hasil DHC mereka membutuhkan perawatan. ${ }^{3}$

\section{DAFTAR PUSTAKA}

1. Rahardjo P. Orthodonti dasar. Surabaya: Airlangga University Press, 2009; p.2-3, 60.

2. Singh G. Textbook of Orthodontics (Second Edition). New Delhi: Jitendra P Vij, 2007; p.3.

3. Foster TD. Buku Ajar Ortodonsia (Edisi Ketiga). Yuwono L, Translator. Jakarta: Buku Kedokteran EGC, 1999; p.29-166.

4. Specialist dental group. Orthodontic [homepage on the Internet]. 2010 [cited 2010 Aug 13]. Available from: URL 
104 Jurnal e-GiGi (eG), Volume 1, Nomor 2, September 2013, hlm. 99-104

:http//www.specialistdentalgroup.com/ortho dontic.php

5. Pakpahan EL, Hoesin F, Krisnawati. Kebutuhan perawatan ortodonti remaja SLTP usia 12-13 tahun di Jakarta Selatan. Jurnal Kedokteran Gigi. 2005;17(2):41-9.

6. Dewi O. Hubungan maloklusi dengan kualitas hidup pada remaja dikota medan. Jurnal Fakultas Kedokteran Gigi Universitas Sumatra Utara. 2009;14(2):115-9.

7. Musyulianti. Kebutuhan perawatan ortodonsi pada SMP Eben Heazer I Manado
[Skripsi]. Manado: Program Studi Kedokteran Gigi Fakultas Kedokteran Universitas Sam Ratulangi; 2010; p.36.

8. Ending S. Kebutuhan perawatan ortodonsi pada SMA kecamatan Malalayang Manado[ Skripsi]. Manado: Program Studi Kedokteran Gigi Fakultas Kedokteran Universitas Sam Ratulangi; 2011; p.34.

9. Sarwono SW. Psikologi Remaja. Jakarta: Rajawali Pers, 2010; p.11-2. 